MAREK WALANCIK

ORCID 000000200918167

Akademia WSB

w Dąbrowie Górniczej

\title{
SYMBOLE WIELOKULTUROWOŚCI W PRZESTRZENI PUBLICZNEJ NA RZECZ PRZECIWDZIAŁANIA NIETOLERANCJI
}

\begin{abstract}
AвSTRACт. Walancik Marek, Symbole wielokulturowości w przestrzeni publicznej na rzecz przeciwdziałania nietolerancji [Symbols of Multiculturalism in Public Space to Counteract of Intolerance]. Studia Edukacyjne nr 56, 2020, Poznań 2020, pp. 111-127. Adam Mickiewicz University Press. ISSN 1233-6688. DOI: $10.14746 /$ se.2020.56.6
\end{abstract}

In the article, the author addresses the issue of the essence and role of the symbol of multiculturalism in public space in the context of counteracting intolerance. The presented text contains not only a presentation of basic terms and theories, but also an analysis of empirical research results related to the issue of the significance of the symbol of multiculturalism in order to counteract intolerance. Frequently appearing facts of intolerance towards culturally different individuals lead to reflection and seeking answers to the question: Does the presence of a symbol of multiculturalism in public space, which was once a borderland space, and today is saturated with various forms of symbols of multiculturalism of the past and of the modern period affect behavior tolerance.

Key words: education, culture, intolerance, symbols, multiculturalism, borderland, public space

\section{Wprowadzenie}

Z każdym miejscem, miastem, miejscowością związane są losy postaci. Niektóre znane są powszechnie - są ich ikonami, jak na przykład Mikołaj Kopernik dla Torunia, Jan Kiepura dla Sosnowca, Jan Paweł II dla Wadowic, Lech Wałęsa dla Gdańska, czy Ignacy Paderewski dla Poznania, a inne poznajemy znajdując się $\mathrm{w}$ przestrzeni danej miejscowości, miasta, regionu.

Jakie losy były udziałem postaci - symboli wielokulturowości, które charakteryzują współczesne miasta, społeczności, kiedyś miasta pogranicza, wielokulturowe, na przykład Chorzów w Polsce w regionie Górnego 
Śląska? Chorzów jako miasto liczy już $773^{1}$ lata. Przez 633 lata znajdował się pod wpływami czeskimi, morawskimi, austro-węgierskimi, pruskimi, niemieckimi - było to miejsce, miasto pogranicza, gdzie, jak piszą R.R Alvarez, G.A Collier, wchodziły w interakcje różne kultury ${ }^{2},(. .$.$) miasto, w którym$ mieszkała ludność polska, niemiecka, żydowska, w różnych proporcjach" ${ }^{\prime 3}$. Żydzi modlili się w synagodze, ewangelicy, chrześcijanie chodzili do własnych kościołów. Jaka współcześnie istnieje znajomość młodego pokolenia postaci, które niezaprzeczalnie można nazwać symbolami miasta Chorzowa, takich jak: Kurt Alder - naukowiec chemik, noblista, Józef Czempiel - błogosławiony ksiądz, działacz narodowościowy i społeczny, św. Florian - oficer legionów rzymskich, Erdman Teodor Kalide - genialny artysta rzeźbiarz, Juliusz Ligoń - działacz społeczno-narodowościowy, artysta i twórca ludowy, Karol Miarka - działacz narodowościowy, Franz Waxman - genialny kompozytor, dyrygent i autor muzyki filmowej, dwukrotny zdobywca Oskara, czy też hrabia Friedrich Wilhelm von Reden - założyciel Konigshutte, dzisiejszego Chorzowa? Każda z tych postaci część swego życia związała z Królewską Hutą, później Chorzowem, które było miastem pogranicza. Niektórzy z nich urodzili się w Chorzowie, spędzili w nim młodość, a następnie wyjechali, inni przybyli, osiedli na dłużej lub na stałe, jeszcze inni za zgodą społeczności (np. św. Florian) stali się patronami miasta. Każda $\mathrm{z}$ tych postaci jest swoistym symbolem wytrwałości w dążeniu do celu, dyplomacji, geniuszu artystycznego. Wszystkie stanowią symbol możliwości współistnienia w społeczeństwie wielokulturowym, gdzie każda jednostka ma miejsce do samorealizacji, a jej działalność tylko wzbogaca całe społeczeństwo. Rozważania te wpisują się w teorię słabych granic społecznych, a mocno geopolitycznych ${ }^{4}$. Idąc za myślą Jerzego Nikitorowicza:

tylko pogranicze daje szansę zrozumienia innych, ich poglądów, racji, zachowań, akceptacji, szacunku dla innych i odmienności. Tylko pogranicze nie dopuszcza do odrzucenia innych czy narzucania innym własnych poglądów, schematów. Uczy

${ }^{1}$ Chorzów otrzymał prawa miejskie 24 czerwca 1257 roku, z rąk księcia opolskiego Władysława w Czeladzi. Jego dziedzictwo kulturowe tworzyli Polacy, Niemcy, Morawianie i ludność żydowska, co było odzwierciedleniem przynależności politycznej Śląska do państwa wielkomorawskiego, Czech, Polski Piastów i Jagiellonów, Węgier, Austrii, państwa pruskiego i cesarstwa niemieckiego. Zob. M. Walancik, Działania edukacyjne i oświatowe w pedagogice międzykulturowej stużące zapobieganiu wykluczeniu kulturowemu społeczności lokalnej - na przykładzie Königshütte Królewskiej Huty - Chorzowa, [w:] Pedagogika międzykulturowa wobec wykluczenia społecznego i edukacyjnego, red. T. Lewowicki, A. Szczurek-Boruta, J. Suchodolska, Cieszyn - Warszawa - Torun 2011, s. 349-360.

2 R.R., Alvarez, G.A. Collier, The Long Haul in Mexican Trucking: Traversing the Borderlands of the North and the South, American Ethnologist, 1994, 21, 3, s. 601.

3 J. Drabina, Historia Chorzowa od 1868 do 1945 roku, Chorzów 1999, s. 6.

${ }^{4}$ H. Campbell, Female Drug Smugglers on the U.S.-Mexico Border: Gender, Crime, and Empowerment, Anthropological Quarterly, 2008, 81, 1, s. 233-267. 
współistnienia, współpracy, życzliwości, otwartości, tym samym stwarzając mniejsze przyzwolenie na nietolerancję i obojętność. Pogranicze pozwala na wypracowanie nowych strategii, na dokonywanie przekształceń w schematach myślenia 5 .

Celem autora niniejszego artykułu jest poznanie i opis, na podstawie badań, jak są postrzegane symbole wielokulturowości w przestrzeni publicznej społeczności w przeszłości pogranicza, na co wpływają, jak kształtują nasze postawy, zachowania wobec osób różniących się kulturowo? Obecność symboli o charakterze wielokulturowości przyjmuję jako formę edukacji międzykulturowej. W opinii autora, takie działania promują postawy tolerancji, dialogu, otwartości, akceptacji, wyzbywania się uprzedzeń.

\section{Symbol, symbolizm w życiu społecznym}

W ujęciu potocznym,

symbol to pewien znak umowny, pełniący funkcję zastępczą przedmiotu, przywodzący na myśl ten przedmiot. Symbol zastępuje jedno pojęcie innym, krótszym, bardziej wyrazistym, lepiej oddającym jego naturę, albo mniej abstrakcyjnym ${ }^{6}$.

\section{Zdaniem Janusza Gajdy,}

symbol to też postać, która jest znakiem treści bezpośrednio nieujawnionych, ale kierujących jednocześnie na nie uwagę na podstawie bliżej nieokreślonej analogii ${ }^{7}$

Symbolizm - w znaczeniu filozoficznym - jest teorią form symbolicznych, które właściwe są umysłowi, a ich poznawcze funkcje, to syntetyzowanie, integrowanie i organizowanie całości doświadczenia (Szkoła Marburska). Szerzej - symbolizm jest teorią natury symbolicznej (ujęcie E. Cassierera), „wytwory kultury pełnią określoną funkcję symboliczną; wszystkie zjawiska kultury kształtują pewien obraz świata, pełnią jednolitą funkcję poznawczą"8. W ten właśnie sposób człowiek tworzy, postrzega swój świat, a w większości przypadków jest to świat symboli. Człowiek nadaje znaczenie zjawiskom, przedmiotom, zachowaniom, a symbole $\mathrm{w}$ tym przypadku są wyrazem jego intelektualnych możliwości, tworzą w ten oto sposób system znaków przyjętych przez społeczeństwo, który zapewnia możliwości komunikowania się99.

\footnotetext{
${ }^{5}$ J. Nikitorowicz, Pogranicze, tożsamość, edukacja międzykulturowa, Białystok 2001, s. 17.

6 J. Otte, R. Szopa, Symbole Chorzowa, Chorzów 2000, s. 5.

7 J. Gajda, Antropologia kulturowa. Wprowadzenie do wiedzy o kulturze, Część 1, Torun 2003, s. 35 .

8 A. Podsiad, Stownik terminów i pojęć filozoficznych, Warszawa 2000, s. 848-849.

9 J. Gajda, Antropologia kulturowa, s. 36.
} 
Ludzie potrafią przedstawiać swoje doświadczenia, świat, odczucia, właściwie wszystko co ich dotyczy za pomocą znaków. „Znaki te nazywamy symbolami wówczas, kiedy ludzie uzgodnią między sobą, jaka jest zawartość znaczeniowa danego znaku i co on przedstawia"10. Badaniem interakcji dokonujących się z użyciem symboli i gestów znaczących zajmuje się interakcjonizm symboliczny. Teoria ta zakłada, że rzeczywistość społeczna wyłania się z interakcji między jednostkami i zbiorowościami, kształtowanych przez znaczenie komunikatywne za pośrednictwem symboli. Twórcy tej orientacji socjologicznej Charles H. Cooley i George H. Mcad twierdzili, że

(...) w interakcji wymiana i wzajemność dotyczą nie tyle obiektów materialnych, co idei, symboli, znaczeń. Najważniejszy w tak rozumianej interakcji jest cały złożony proces myślowy, który rozwija się po obu stronach, od momentu zetknięcia się partnerów ze sobą ${ }^{11}$.

Nie bez powodu należy zastanowić się, jakie miejsce w życiu społeczności zajmuje symbol, bez względu na przeobrażenia kulturowe zachodzące w danym okresie i bez względu na to, w jakiej relacji miedzy kulturami dana społeczność funkcjonuje. Alfred N. Whitehead w 1927 roku stwierdził, że „Żadna społeczność nie może istnieć bez symbolizmu"12, a Émile Durkheim, iż „(..) wszelkie postacie życia społecznego w każdym momencie dziejów mogą istnieć tyko dzięki rozległemu systemowi symboli"13. Współcześnie Pierre Bourdieu formułując teorie społecznego systemu symbolicznego wskazuje, że „(...) świat społeczny przedstawia się, obiektywnie, jako system symboliczny zorganizowany według logiki różnicy $(. . .)^{\prime 14}$.

Antropolodzy symboliczni (C. Geertz, D. Schneider, V.W. Turner oraz M. Douglas) uważają kulturę za sieć komunikacyjną, która „uwzględnia znaki werbalne i niewerbalne, empiryczne i nieempiryczne oraz różne aspekty i dziedziny, włącznie ze społecznymi, ekonomicznymi i politycznymi"15. Jednak Clifford Geertz spostrzegał kulturę w dwóch aspektach: z jednej strony kultura jest "modelem czegoś”, co oznacza nadawanie sensu, z drugiej „modelem dla", jako mentalny wzór zachowań. Symbole zaś w tym przypadku, to systemy planów, których badanie jest jednoznaczne $\mathrm{z}$ badaniem istoty kultury, albowiem według C. Geertza, ten cały system wyobrażeń, znaczeń wie-

${ }^{10}$ J.H. Tuner, Socjologia. Koncepcje i ich zastosowanie, Poznań 1988, s. 40.

11 P. Sztompka, Socjologia. Analiza społeczeństwa, Kraków 1988, s. 77.

12 A.M. Whietehead, Symbolizm. Meanig and Effect, New York (1927) 1985, s. 1.

${ }^{13}$ É. Durkheim, Elementarne formy życia religijnego. System totemiczny w Australii, przekł. A. Zadrożyńska, Warszawa 1990, s. 223.

${ }_{14}$ P. Bourdieu, Social Space and Symbolic Power, Sociological Theory, 1989, 7, 1, s. 20.

${ }^{15}$ E. Krawczak, Antropologia kulturowa, klasyczne kierunki, szkoty i orientacje, Lublin 2006, s. 171. 
dzy o życiu, przekazywaniu tejże wiedzy i stosunku do tegoż znajduje swoje odbicie właśnie w symbolach ${ }^{16}$.

Burrhus Frederic Skinner uważa, że kultura jest zbiorem obyczajów, które można mieszać $\mathrm{z}$ innymi ${ }^{17}$. Jak pisze Janusz Gajda,

Kontakt kultur prowadzi do integracji między ich nosicielami i zachodzi w wyniku ruchów ludno- (migracji) lub jest wyrazem świadomego oddziaływania reprezentantów jednej, aktywnej kultury, na reprezentantów innych - zazwyczaj pasywnych albo po prostu stanowi układ bezpośrednich lub pośrednich wzajemnych stosunków kulturowych ${ }^{18}$.

\section{Symbole w wielokulturowej przestrzeni pogranicza}

Tam, gdzie istnieją różne kultury, różni ludzie, różne doświadczenia i różna historia społeczeństw, funkcjonują różne symbole, znaczenia. Wykluczają się wzajemnie, przeciwstawiają sobie, funkcjonują w symbiozie, przenikają z jednej kultury do drugiej, najczęściej wśród społeczności pogranicza. Pogranicze to sąsiedztwo kultur, jednak nie jest to wyłącznie przestrzeń społeczna, ale także historycznie zmienna sytuacja ${ }^{19}$. Termin pogranicze, według Jerzego Nikitorowicza,

(...) najczęściej wiąże się z obszarem pomiędzy centrami, pomiędzy tym, co znajduje się na granicach i przynależeć może do obu centrów, zachodząc na siebie. Opuszczając centrum, które najczęściej jest sztywne i zamknięte, wchodzimy do obszaru zróżnicowań, inności i odmienności, gdzie możemy porównywać, odkrywać, wykazywać zdziwienie, negocjować itp. Jednakże grupa dominująca winna stwarzać warunki ułatwiające opuszczanie centrum, zaś, by spojrzeć na siebie i własne idee z drugiej strony z uwzględnieniem racji innych, muszą zaistnieć sprzyjające sytuacje $\mathrm{e}^{20}$. Pogranicze wyzwala tolerancję powiązaną z wolnością i odpowiedzialnością, tworzy układy dialogowe, (...) Jednakże tyko wówczas możemy zrozumieć odmienność i przeżywać ją, gdy znamy i cenimy własną kulturę, dzięki czemu możemy porównywać i odnosić ją do innych nie w kategoriach lepsze - gorsze, ale w kategoriach inne, niezrozumiałe, ciekawe, zastanawiające, inspirujące ${ }^{21}$.

Należy także zaakcentować fakt, że pogranicze stwarza możliwość wyboru, kształtowania postaw, wartości, idei opartych na wartościach obu czy też wielu kultur, gdzie można czerpać wzory z tradycji ludzi żyjących obok,

16 Tamże, s. 174.

17 B.F. Skinner, Poza wolnościa i godnościa, przekł. W. Szelenberger, Warszawa 1978, s. 151.

18 J. Gajda, Antropologia kulturowa, s. 109.

19 A. Kłoskowska, Otwarte i zamknięte postawy narodowe w sytuacji pogranicza, Kultura i Społeczeństwo, 1995, 39, 3.

20 J. Nikitorowicz, Pogranicze, tożsamość, s. 11.

21 Tamże, s. 8. 
przyjmować ich wzorce, modyfikować własne lub też je utrwalać. Mieszkańcy pogranicza mogą być „takim i takim, mimo cech różniących, przypisujących ich do określonej wyznaniowej czy etnicznej"22. To właśnie ta wielokulturowość, umiejętność funkcjonowania obok siebie i wspólnie ze sobą daje szansę wzbogacenia samego siebie, tak pod względem poznawczym, jak i emocjonalnym, moralnym.

Wielokulturowość jest pojęciem złożonym. Andrzej Sadowski pojęcie to rozumie jako:

zinstytucjonalizowane na zasadach demokratycznych współżycie w obrębie państwa jednostek, wspólnot i innych form zbiorowości cechujących się wyartykułowaną społecznie tożsamością kulturową. (...) Samo współwystępowanie dwóch lub więcej grup kulturowych nie oznacza istnienia wielokulturowości. Wówczas mamy do czynienia ze zróżnicowaniem kulturowym. Z fenomenem wielokulturowości mamy do czynienia dopiero wówczas, kiedy dochodzi do trwałych form kontaktów międzykulturowych, które powodują wytworzenie się kulturowo różnorodnej całości ${ }^{23}$.

Każda kultura i jej uczestnicy mają własny świat symboli funkcjonujących w życiu codziennym niezmienne. Jednakże może być i tak, że w zderzeniu z Innymi, z którymi dzielimy terytorium, którzy w naturalny sposób, codziennie są także z nami ze swym światem symboli, przyjmujemy ich świat za swój, dając im możliwość korzystania z naszego. I ciągle nie wiemy,

czy będzie to świat anomii, świat relatywności rozbijającej wszystko, co wspólne i trwale, czy też z tego "chaosu kulturowego", jak często nazywany bywa nasz czas, wyłoni się nowy kształt, który będzie można określić w kategoriach sensu²4.

W przeszłości symbole były więzią, która łączyła daną społeczność, decydowała o przynależności jednostki do danej kultury, były niepodważalną wartością.

Wśród wielu definicji przestrzeni publicznej zapewne stwarza ona możliwości zaistnienia w niej symboliki kultury, wielokulturowości. Przestrzeń publiczna to przestrzeń, do której wszyscy mają łatwy dostęp, w której mogą się spotykać, zachodzą między nimi interakcje, czują się bezpiecznie ${ }^{25}$.

Jak symbole funkcjonują obecnie w przestrzeni publicznej, kiedy zmieniamy miejsca pobytu, a świat się skurczył, stał się globalną wioską, kiedy wyjeżdżamy, wracamy,

${ }^{22}$ Tamże, s. 12.

${ }^{23}$ A. Sadowski, M. Czerniawska, (red.), Tożsamość Polaków na pograniczach, Białystok 1999, s. 33.

${ }^{24}$ A. Przecławska, Symbole w życiu wspótczesnej młodzieży - wyniki badań przeprowadzonych w środowisku dorosłej młodzieży Warszawy, Kultura i Społeczeństwo, 1995, 3, s. 143.

${ }^{25}$ K. Bierwiaczonek, Społeczne znaczenie miejskich przestrzeni publicznych, Katowice 2016, s. 42. 
pozostajemy w nowych miejscach, a jeśli wracamy, to duchowo, kulturowo zmienieni? Czy dostrzegamy w naszych społecznościach, często będących w określonym czasie społecznościami pogranicza, symbole wielokulturowości? Jaką one mają formę, postać? Jaki mają wpływ na kształtowanie naszych postaw, w stosunku do Innych? Zasadne jest także pytanie o źródła tych symboli - czy jest to przede wszystkim uczestnictwo w kulturze, operującej paletą społecznie usankcjonowanych wzorów i modeli, czy też osobiste doświadczenia życiowe pozwalające na wytworzenie symboli jednostkowych? (...) I jaki jest udział kultury powszechnej w wytwarzaniu symboli jednostkowych, nawet jeśli nie jest on uświadamiany? ${ }^{26}$.

Na wybrane pytania autor poszukuje odpowiedzi poprzez eksploracje. Poniżej zaprezentowano zaledwie wycinek wyników badań i wniosków.

\section{Założenia metodologiczne badań}

Erall Babbi przyjmuje, że celem badania jest eksploracja, opis i wyjaśnienie problematyki badawczej ${ }^{27}$. W prezentowanym przypadku celem był opis, zbadanie i wyjaśnienie: Czy symbole wielokulturowości powstałe w dawnym rejonie pogranicza są dostrzegane w przestrzeni publicznej współcześnie? W jakim stopniu znajomość losów, postaci symboli, może wpłynąć na kształtowanie postaw tolerancji, otwartości? Jakie mogą być skutki obecności symboli o charakterze wielokulturowości w przestrzeni publicznej społeczności?

Badania przeprowadzono w kwietniu i maju 2017 roku. Uczestniczyła w nich młodzież szkół ponadpodstawowych Chorzowa, a zastosowaną metodą był sondaż diagnostyczny, technika ankiety, zaś narzędziem - samodzielnie zaprojektowany kwestionariusz ankiety. Skonstruowano go opierając się na kafeterii dysjunktywnej (badany miał do wyboru jedną odpowiedź), jak i koniunktywnej (badany miał do wyboru 2 - 6 odpowiedzi). W badaniu wzięło udział 627 osób. Do analizy zakwalifikowano 609 wypełnionych kwestionariuszy. Wyniki badań przedstawiono w procentach.

\section{Symbole wielokulturowości w przestrzeni publicznej - analiza wyników badań}

W opinii Romana Ruczyńskiego:

obiekty użyteczności publicznej i przestrzenie publiczne stanowią formy, które w przeważającej mierze tworzą tożsamość miasta. Częstokroć stają się symbolami miasta, kreując nierozerwalne związki: Moskwa - plac Czerwony, Paryż - wieża Eiffla lub

\footnotetext{
${ }^{26}$ A. Przecławska, Symbole w życiu współczesnej młodzieży, s. 145.

27 E.R., Babbie, Badania społeczne w praktyce, Warszawa 2004, s. 112-113.
} 
wielka oś, Wenecja i plac Świętego Marka. Przykłady takie można mnożyć i wszystkie wskazują na wiodącą dla kwestii rozpoznawalności miasta rolę przestrzeni i obiektów użyteczności publicznej. One najsilniej wpływają na obraz miasta i decydują o jego niepowtarzalności ${ }^{28}$.

Istotne dla procesu badań było poznanie, z jakimi postaciami - symbolami charakterystycznymi dla wielokulturowości, występującymi w przestrzeni publicznej kojarzone jest współcześnie miasto Chorzów.

Badanym zaproponowano wskazanie postaci - symbolu związanego z Chorzowem, z jego przestrzenią publiczną z okresu wielokulturowości przełomu XIX - XX wieku i współczesności, na przykład Hrabia von Reden, Franz Waxman, a współczesne Ryszard Riedel, Mirosław Breguła. Badani mieli możliwość wskazania co najmniej trzech postaci, a dane przedstawia rycina 1.

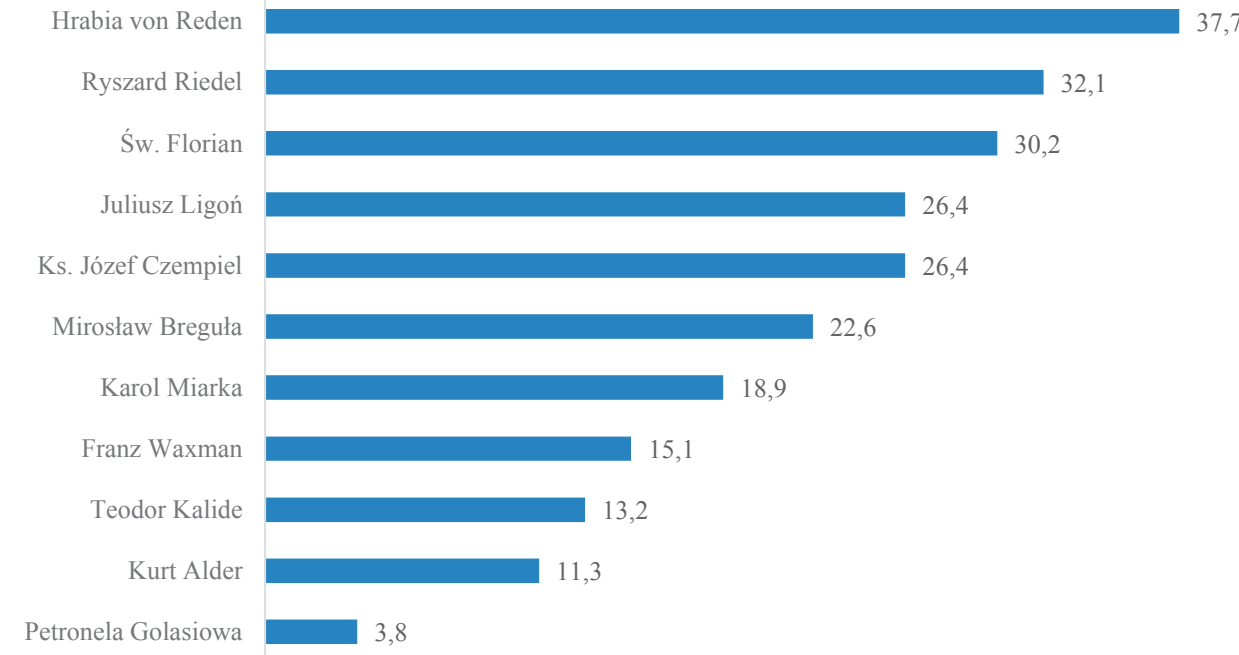

Ryc. 1. Postacie - symbole wielokulturowości kojarzone z Chorzowem w percepcji badanych (N 609)

(źródło: opracowanie własne)

$\mathrm{Z}$ analizy danych wynika, iż badani kojarzą postaci - symbole w przestrzeni publicznej miasta z Chorzowem. Na samym początku wskazali, że Chorzów kojarzy im się z postacią hrabiego von Redena (37,7\%). Należy dodać, iż w centrum miasta (ok. 200 m od ratusza) znajduje się pomnik Redena,

${ }^{28}$ R. Ruczyński, Tradycyjna urbanistyka a wspótczesne realizacje przestrzeni publicznych, [w:] Problemy ksztattowania przestrzeni publicznych, red. P. Lorens, J. Martyniuk-Pęczek, Gdańsk 2010, s. 151. 
a nieopodal park wypoczynku z Górą Wyzwolenia - niegdyś Park Redena i Góra Redena ${ }^{29}$, gdzie pomnik był pierwotnie usytuowany. Następnie wymienili postaci Ryszarda Riedla (32,1\%) i św. Floriana (30,2\%). Ryszard Riedel (1956-1993) - polski wokalista i autor tekstów piosenek - urodził się i zmarł w Chorzowie. Prestiżowy amerykański magazyn „Rolling Stone” określił go jako "ostatniego hippisa naszych czasów”. Z kolei św. Florian to postać historyczna - nigdy nie był w Chorzowie, nie przebywał w Polsce. $Z$ regionem Górnego Śląska, Śląska Cieszyńskiego jest związany jako postać-symbol strażaków i hutników, a z Chorzowem - poprzez tradycje hutnicze (na terenie miasta istniały dwie huty). Chorzów, decyzją Rady Miasta, w 1993 roku przyjął św. Floriana za swojego patrona ${ }^{30}$. W Chorzowie znajduje się Sanktuarium św. Floriana, a w 2015 roku jedno z rond nazwano jego imieniem i postawiono tam jego posąg. Zatem, w przestrzeni publicznej jest fizycznie postacią występującą. Prawie jedną piątą wskazań otrzymał Karol Miarka (18,9\%) polski działacz społeczny na Górnym Śląsku, nauczyciel, pisarz, publicysta i drukarz ${ }^{31}$. Z jego inicjatywy powstało wiele polskich organizacji społecznych i gospodarczych na Górnym Śląsku, w tym w Chorzowie. Na kolejnych miejscach badani wskazali postaci: Juliusza Ligonia - działacza społecznego, poety ludowego, publicysty ${ }^{32}(26,4 \%)$ i ks. Józefa Czempiela $(26,4 \%)$, a następnie Mirosława Breguły (22,6\%) - współzałożyciela i lidera zespołu muzycznego Universe, 43-letniego tragiczne zamarłego w 2007 roku artysty.

Podobnie odniesiono się do postaci Franza Waxmana (15,1\%), Teodora Kalide (13,2\%), Kurta Aldera ${ }^{33}(11,3 \%)$, a na ostatnim miejscu usytuowano Petronelę Golasiową (3,8\%). Warto podkreślić, iż badani wskazali, że dostrzegają $\mathrm{w}$ przestrzeni publicznej miasta symbole, postacie osób - te z minionego okresu, jak i współczesne. Są to symbole personifikujące różnorodność społeczną, narodowościową, wyznaniową, wielokulturowość, postacie wpisujące się w przestrzeń publiczną miasta Chorzowa. Można zatem pokusić się o wnioski, że ludzie młodzi znają historię swojego miasta, jego wielokulturowy ryt, symbolikę, która wpisuje się w wizerunkowy charakter miasta.

${ }^{29}$ http://pelniakultury.pl/miejsca/pokaz/167/Park_Redena_Park_na_Gorze_Wyzwolenia_w_Chorzowie [dostęp:12.12. 2018].

${ }^{30}$ Rada Miejska w Chorzowie podjęła Uchwałę nr LV/402/93 z 15.07.1993 r. popierającą starania duchowieństwa chorzowskiego odnośnie sprowadzenia z Krakowa do Chorzowa relikwii św. Floriana oraz ustanowienia św. Floriana patronem miasta; Uchwała nr IX/138/15 z 28.05.2015 r. w sprawie nadania nazwy rondu u zbiegu ulic 75 Pułku Piechoty i Nomiarki w Chorzowie „Rondo świętego Floriana - Patrona Miasta”; Uchwała nr VIII/115/15 z 30.04.2015 r. w sprawie umieszczenia figury św. Floriana - patrona miasta Chorzów na rondzie u zbiegu ulic 75 Pułku Piechoty i Nomiarki w Chorzowie.

31 R. Hanke, Polska droga do Chorzowa. Opowieści z dziejów Chorzowa, Chorzów 1988, s. 47-51.

${ }^{32}$ Tamże, s. 288-289.

${ }^{33}$ M. Walancik, Działania edukacyjne i oświatowe w pedagogice międzykulturowej, s. 349-360. 
Bronisław Malinowski pisał: „Wciąż brakuje nam jasnej definicji procesu symbolicznego"34. Z jednej strony symbol odnosi się do tego co wyimaginowane, odbiegając tym samym od rzeczywistości, z drugiej zaś łączy się z kodem poznawczym, jakiego dostarcza kultura ${ }^{35}$. W ujęciu Małgorzaty Dymickiej, przestrzeń publiczna otwarta jest na różnorakie relacje ${ }^{36}$. W badaniach zapytano uczestników, czy dostrzegają symbole wielokulturowości w przestrzeni społecznej Chorzowa? Dane obrazuje rycina 2.

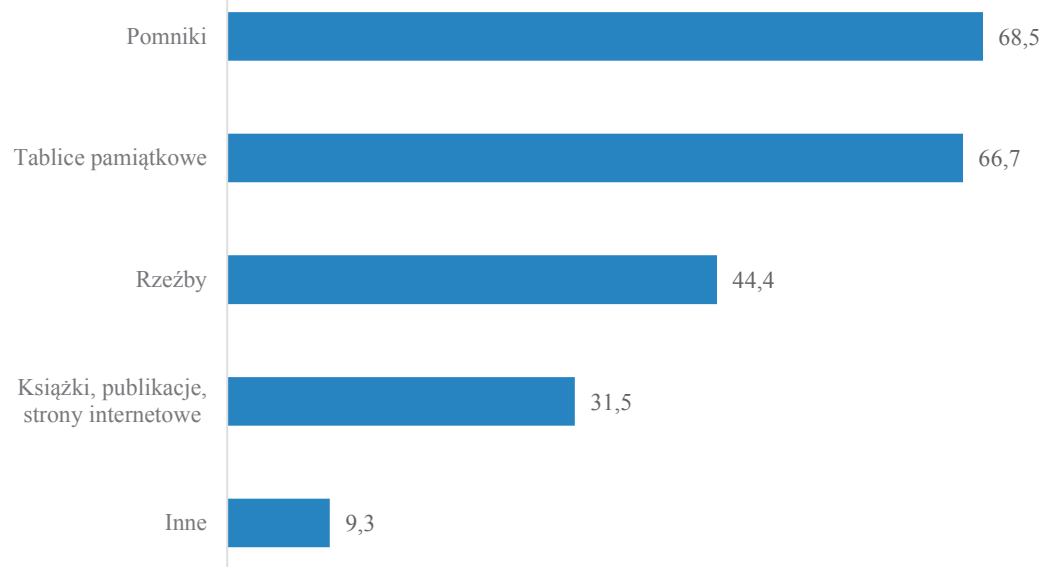

Ryc. 2. Symbole wielokulturowości w przestrzeni miasta Chorzowa (N 609) (źródło: opracowanie własne)

Badani zdecydowanie wskazali, że w przestrzeni publicznej miasta dostrzegają pomniki $(68,5 \%)$ jako symbole wielokulturowości. Pomimo że formą pomnika są również tablice pamiątkowe i rzeźby, formy te w pytaniu rozdzielono. Pomniki stanowiące symbol wielokulturowości w Chorzowie i podane przez badanych, to pomnik hrabiego Friedricha Wilhelma von Redena, Gutenberga, figura św. Floriana, św. Jana Nepomucena, pomnik upamiętniający społeczność żydowską. Na drugim miejscu wskazano tablice pamiątkowe $(66,7 \%)$. W Chorzowie jest ich kilkanaście, a związane z problematyką wielokulturowości, w opinii badanych, poświęcono Franzowi Waxmanowi ${ }^{37}$, Ryśkowi Riedlowi ${ }^{38}$, Kalidemu, Kurtowi Alderowi i innym.

${ }^{34}$ B. Malinowski, Kultura, społeczność, jednostka, przekł. S. Kapralski, J. Otrębski, Warszawa 2000, s. 189. 1987.

${ }^{35}$ E. Hałas (red.), Społeczny kontekst znaczeń w teorii symbolicznego interakcjonizmu, Lublin

36 M. Dymnicka, Przestrzeń publiczna a przemiany miasta, Warszawa 2013, s. 63.

${ }^{37}$ K. Knas, Ważne jest miejsce pamięci, Wspólny Chorzów, 2006, 12(135), s. 8.

${ }^{38}$ W. Zawadzki, Longplay dla Ryśka, "Chorzowianin", 2006, 45, (318). 
W rozumieniu autora, obecność symboli wielokulturowości w przestrzeni publicznej daje zdecydowanie większe uczestnictwo społeczności i kontakt $\mathrm{z}$ nimi, wpisują się $\mathrm{w}$ tak zwane szerokie uczestnictwo $\mathrm{w}$ kulturze, zatem pozwalają na:

- część praktyk związanych z relacjami łączącymi ludzi i przedmioty materialne oraz idee;

- praktyki kulturalne dotyczące relacji jednostki z otoczeniem społecznym (np. spotkania towarzyskie);

- praktyki kulturalne odnoszące się do różnego typu kręgów społecznych otaczających jednostkę, widziane w perspektywie „kultury życia codziennego" zbiorowości ${ }^{39}$.

Z punktu badawczego istotne było poznanie opinii, co wyrażają symbole o formie wielokulturowości, na co wpływają w przestrzeni miejskiej (ryc. 3).

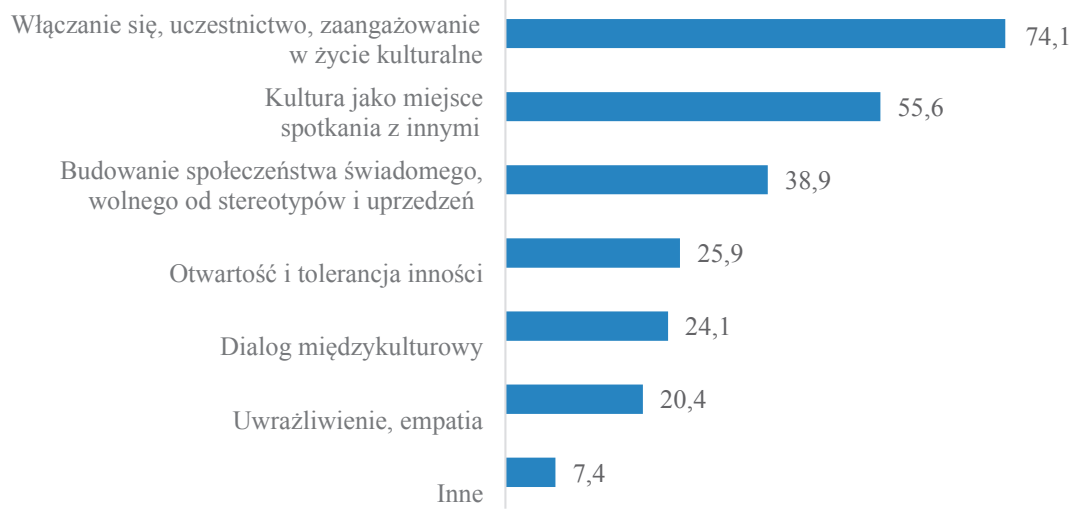

Ryc. 3. Promowanie postaw przez symbole o charakterze wielokulturowości (N 609)

(źródło: opracowanie własne)

W ocenie badanych, symbole wielokulturowości w przestrzeni publicznej miasta sprawiają, iż kształtują się nasze postawy kulturalizacyjne ${ }^{40}$. Włączamy się, uczestniczymy, angażujemy w życie kulturalne społeczności $(74,1 \%)$. Powyższe wskazania korelują z danymi CBOS-u, z których wynika, iż systematycznie zwiększa się zaangażowanie Polaków w działania społeczności

${ }^{39}$ Zob. B. Fatyga, Uzasadnienia szczegótowe do wyodrębnionych części kwestionariusza, [w:] Praktyki kulturalne Polaków, red. R. Drozdowski i in., Toruń 2014, s. 27.

${ }^{40}$ E. Ogrodzka-Mazur, Między etnicznościa a integracją. Strategie kulturalizacyjne przyjmowane przez społeczności szkót z polskim językiem nauczania, Lubelski Rocznik Pedagogiczny, 2017, XXXVI, 3, s. 62.-76. 
lokalnych, zwłaszcza dotyczących spraw publicznych, w tym kulturalnych, szczególnie w wymiarze lokalnym ${ }^{41}$.

Obecność symboli o charakterze wielokulturowości w przestrzeni publicznej społeczności lokalnych wpisuje się w kształtowanie postaw kulturalizacyjnych - szeroko rozumianą kulturę. Miejsca usytuowania symboli, okoliczności związane z ich instytucjonalizacją sprawiają, iż stają się miejscem spotkań z Innymi (55,6\%). Obecność symboli o charakterze wielokulturowości w przestrzeni publicznej miasta przyczynia się do budowania postaw świadomych, wolnych od stereotypów i uprzedzeń $(38,9 \%)$. Ich obecność sprawia, że stajemy się otwarci na innych i tolerancyjni (25,9\%), są formą dialogu międzykulturowego, na co wskazała jedna czwarta badanych, przyczyniając się do poznawania innej kultury. Dialog jest dla nas istotnym źródłem wiedzy o kulturze innych, ich wartościach, ale też o sobie samym, naszej kulturze, rozumieniu innych. Może on przewartościować pewne obszary własnej kultury, które do tej pory były nie do przewartościowania. Działania takie w opinii badanych uwrażliwiają, sprawiają, że jesteśmy bardziej empatyczni, zauważamy bardziej problemy innych.

Suma wskazań w opinii badanych kategorii „w stopniu umiarkowanym”, „w dużym stopniu”, ,"w bardzo dużym stopniu”, wpływu znajomości historii miasta oraz obecności symboli o charakterze wielokulturowości w przestrzeni publicznej społeczności na przezwyciężenie nietolerancji, na akceptację inności jest wysoka i wynosi $65 \%$. Z kolei suma wskazań kategorii „w niewielkim stopniu” i „w żadnym stopniu” wyniosła 35\%. W ocenie autorów badań, na podstawie powyższych wyników można wnioskować, iż należy podejmować różnorodne działania i stosować różnorodne formy na rzecz przeciwdziałania nietolerancji, akceptacji inności. Mają one właśnie sens w systemie działań.

Badanych zapytano również, w jakim stopniu znajomość historii miasta oraz obecność symboli o charakterze wielokulturowości w przestrzeni publicznej może wpłynąć na akceptację inności? Ich odczucia prezentuje rycina 4.

Badani zdecydowanie wskazali, iż zgadzają się z tezą, że obecność symboli o charakterze wielokulturowości w przestrzeni publicznej umożliwia zachowanie pamięci o przeszłości, pozwalając unikać błędów w działaniu społecznym w przyszłości $(61,1 \%)$. W opinii badanych, ich obecność wpływa na zwiększenie wiedzy na temat otaczającej nas rzeczywistości, przyczyniając się także do zmniejszenia nietolerancji (59,3\%). Ponad połowa badanych (53,7\%) wskazała, że mają wpływ na poprawę umiejętności w komunikacji międzykulturowej. 38,9\% uznało, że symbole o charakterze wielokulturo-

${ }^{41}$ R. Boguszewski, Zaangażowanie Polaków na rzecz społeczności lokalnej, Komunikat CBOS nr 74/2018, s. 6 . 
W stopniu umiarkowanym

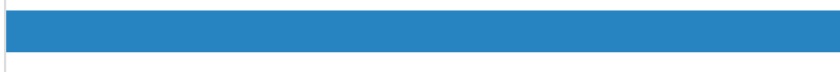

W niewielkim stopniu

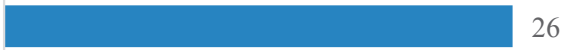

W dużym stopniu

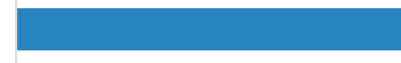

W żadnym stopniu

W bardzo dużym stopniu

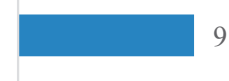

2

Ryc. 4. Znajomość historii miasta, obecności symboli o charakterze wielokulturowości w przestrzeni publicznej społeczności a akceptacja inności (N 609)

(źródło: opracowanie własne)

Zachowanie pamięci o przeszłości pozwalającej na unikanie błędów w działaniu społecznym w przyszłości

Zdobycie wiedzy o otaczającej nas rzeczywistości, przyczyniające się do zmniejszenia nietolerancji

Poprawiają umiejętności w komunikacji międzykulturowej

Umożliwiają debatę na temat postaw społecznych

Zamykanie się przed innością

Może mieć wpyw na uprzedzenia mieszkańców wobec Innych

Budowanie postawy nietolerancji i zamknięcia na inność
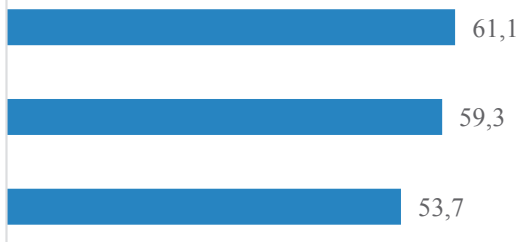

38,9

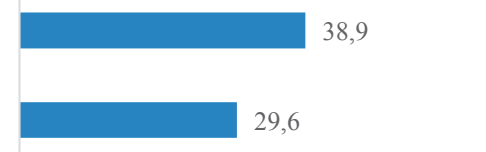

20,4

14,8

Ryc. 5. Skutki obecności symboli o charakterze wielokulturowości w przestrzeni publicznej (N 609)

(źródło: opracowanie własne)

wym w przestrzeni publicznej to debata na temat postaw społecznych. Prawie jedna trzecia badanych twierdzi, że obecność symboli wielokulturowości może prowadzić do zamykania się przed Innością. Z analizy danych wyni- 
ka, że jedna piąta badanych wskazała, że ich obecność może mieć wpływ na uprzedzenia mieszkańców wobec Innych. Zadziwia również fakt, iż 14,8\% podało, że obecność symboli o charakterze wielokulturowości w przestrzeni publicznej jest budowaniem postaw nietolerancji i zamykaniem się na innych.

\section{Podsumowanie}

Społeczeństwa trwają dzięki pamięci przeszłości przekazywanej z pokolenia na pokolenie. Losy społeczeństw związane są z losami jednostek i ich rodzin. Znaczącą rolę odgrywają tu wspomnienia rodzinne, jako fundamenty międzypokoleniowej transmisji ${ }^{42}$, Zatem, warto wspomnienia te przekazywać, uczynić je aktywnymi podmiotami otaczającej rzeczywistości. Często społeczności, ze względu na pełnione role społeczne, same podejmują inicjatywę odnośnie upamiętnienia tych jednostek, poprzez nadanie nazwy ulicy, stawianie pomników, tablic, rzeźb oraz innych form. Ostatnio bardzo popularne stały się tak zwane „ławeczki”.

Zaprezentowana w niewielkim zakresie analiza pozwala wnioskować, że znamienna jest obecność w przestrzeni publicznej symboli wielokulturowości. Ich występowanie i poprzez to udostępnienie mieszkańcom, stanowi nie tylko upiększanie samej przestrzeni w wyrazie estetycznym, wizualnym, jak i zapewne relacyjnym, ale także $\mathrm{w}$ wymiarze edukacyjnym przyczynia się do budowania społeczeństwa otwartości, tolerancji. Obecność symboli odnoszących się do minionych czasów, pokazujących jego wielokulturowość na przestrzeni wieków, w powiazaniu ze znajomością historii miasta, genezą symboli, wpisuje się w budowanie społeczeństwa otwartego na inność, w tożsamość tego społeczeństwa. Właśnie w takim przypadku, jak pisze Zbyszko Melosik, człowiek buduje swoją tożsamość na podstawie dostępnych źródeł kulturowych, jednak "dobierając” je do rdzenia tożsamości, a nie „wymieniając swoją tożsamość na nową, niczym kolejny sezonowy strój" 43 .

W podsumowaniu warto zwrócić uwagę, iż promowanie pokojowego i inkluzywnego społeczeństwa, zapewnienie wszystkim ludziom dostępu do odpowiedzialnych instytucji sprzyjających włączeniu społecznemu ${ }^{44}$ jest 16. celem zawartym w Agendzie na rzecz zrównoważonego rozwoju 2030. Agenda (ang. The Sustainable Development Goals) została przyjęta przez wszystkie

${ }^{42}$ M. Halbwachs, Społeczne ramy pamięci, Warszawa 1968, s. 217-2261; K. Kajdanek i in., Specjalne weekendy Esk, raport podsumowujacy. Ewaluacja Europejskiej Stolicy Kultury, Wrocław 2016.

${ }^{43}$ Z. Melosik, Kultura popularna i tożsamość młodzieży. W niewoli władzy i wolności, Kraków 2013, s. 455.

${ }^{44}$ https:/ / kampania17celow.pl/przeksztalcamy-nasz-swiat-agenda-na-rzecz-zrownowazonego-rozwoju-2030/, 
193 państwa członkowskie ONZ Rezolucją Zgromadzenia Ogólnego 25 września 2015 roku w Nowym Jorku. Zatem, nadrzędne wydają się wszelkie działania związane z obecnością w przestrzeni publicznej innych kultur w różnych formach.

Kiedy w 2017 roku we Wrocławiu zapytano badanych o konsekwencje obecnosci przedstawicieli innych kultur, wskazali oni, że ich obecność wpłynie na wzbogacenie kultury (65,3\%). Kategorię „zwiększenie otwartości mieszkańców wobec innych ludzi“ potwierdziło 60,1\%. Ponad jedna piąta (22,2\%) uznała, że będzie to generować wzrost konfliktów społecznych, a ponad jedna dziesiąta, iż spowoduje wzrost przestępczości $(12,4 \%)^{45}$.

Wsród złożoności symboli w przestrzeni publicznej, społeczeństwa utożsamiają się z symboliką narodową i regionalną (we wrzesniu 2017 roku 96,0\% badanych utożsamiało się z sybolami narodowymi w przestrzeni publicznej ${ }^{46}$ ), ale również utożsamiają się z symbolami wielokulturowości.

Z przeprowadzonej analizy wyników badań własnych można wnioskować, iż „pamięć o przeszłości” pozwala unikać błędów w działaniu społecznym. Znajomość historii miasta poprawia umiejętność w komunikacji międzykulturowej, w budowaniu relacji. Należy podejmować różnorodne działania w dziedzinie obecności symboli o charakterze wielokulturowości $\mathrm{w}$ przestrzeni publicznej. Zdecydowanie rosną oczekiwania współczesnych użytkowników przestrzeni publicznych. Zatem, warto sięgać do przeszłości, ale również wykorzystywać współczesne okazje (niekoniecznie współczesny artysta, twórca musi czekać na ławeczkę latami, do zakończenia aktywności). Jak wskazują dane zawarte na rycinie 4, symbole wielokulturowości mogą stać się przyczynkiem do żywych lekcji historii, obywatelskości, relacyjności społecznych. Ich obecność to między innymi forma edukacji wielokulturowej na rzecz przeciwdziałania nietolerancji, akceptacji inności. Działania takie mają sens, w ocenie autora, są udostępnione społeczności przez cały rok, bezpłatne, skierowane do różnych grup wiekowych, ponadczasowe, uniwersalne. Pozwalają na rozwój inkluzyjnego społeczeństwa oraz promowanie uczenia się przez całe życie.

\section{BIBLIOGRAFIA}

Alvarez R.R., Collier G.A., The Long Haul in Mexican Trucking: Traversing the Borderlands of the North and the South, American Ethnologist, 1994, 21, 3.

Anzaldúa G.E., Borderlands La Frontera: The New Mestiza, Aut Lute Book Company, San Francisco 1987.

Babbie E.R., Badania społeczne w praktyce, Wydawnictwo Naukowe PWN, Warszawa 2004.

${ }^{45}$ K. Kajdanek i in., Specjalne weekendy Esk, raport podsumowujący.

${ }^{46}$ A. Głowacki, Wykorzystywanie symboli narodowych, Raport CBOS nr 133/2017, s. 5. 
Barth Ż., Ethnic Groups and Boundaries: The Social Organization of Culture Difference, Little, Brown and Company, Boston 1969.

Bierwiaczonek K., Społeczne znaczenie miejskich przestrzeni publicznych, Wydawnictwo Uniwersytetu Śląskiego, Katowice 2016.

Boguszewski R., Zaangażowanie Polaków na rzecz społeczności lokalnej, Komunikat CBOS nr 74/2018.

Bourdieu P., Social Space and Symbolic Power, Sociological Theory, 1989, 7, 1, s. 20.

Breidenbach J., Nyíri P., Seeing Culture Everywhere: From Genocide to Consumer Habits, University of Washington Press, Seattle 2009.

Campbell H., Female Drug Smugglers on the U.S.-Mexico Border: Gender, Crime, and Empowerment, Anthropological Quarterly, 2008, 81, 1.

Drabina J., Historia Chorzowa od 1868 do 1945 roku, Wydawnictwo „Profesor", Chorzów 1999.

Durkheim É., Elementarne formy życia religijnego. System totemiczny w Australii, przekł. A. Zadrożyńska, PWN, Warszawa 1990.

Dymnicka M., Przestrzeń publiczna a przemiany miasta, Wydawnictwo Naukowe Scholar, Warszawa 2013.

Fatyga B., Uzasadnienia szczegótowe do wyodrębnionych części kwestionariusza, [w:] Praktyki kulturalne Polaków, red. R. Drozdowski i in., Wydawnictwo Naukowe Uniwersytetu Mikołaja Kopernika, Torun 2014.

Follis K., Building Fortress Europe: The Polish-Ukrainian Frontier, University of Pennsylvania Press, Philadelphia 2012.

Gajda J., Antropologia kulturowa. Wprowadzenie do wiedzy o kulturze, Część 1, Wydawnictwo Adam Marszałek, Torun 2003.

Giddens A., Socjologia, przekł. A. Szulżycka, Wydawnictwo Naukowe PWN, Warszawa 2007.

Głowacki A., Wykorzystywanie symboli narodowych, Raport CBOS, nr 133/2017.

Hałas E. (red.), Społeczny kontekst znaczeń w teorii symbolicznego interakcjonizmu, Wydawnictwo Katolickiego Uniwersytetu Lubelskiego, Lublin 1987.

Hałas E., Symbole i społeczeństwo. Szkice z socjologii interpretacyjnej, Wydawnictwa Uniwersytetu Warszawskiego, Warszawa 2007.

Halbwachs M., Społeczne ramy pamięci, Państwowe Wydawnictwo Naukowe, Warszawa 1968.

Hanke R., Polska droga do Chorzowa. Opowieści z dziejów Chorzowa, Stowarzyszenie Miłośników Chorzowa im. Juliusza Ligonia w Chorzowie, Wydział Kultury i Sztuki Urzędu Miasta w Chorzowie, Chorzów1988.

http:/ / pelniakultury.pl/miejsca/pokaz/167/Park_Redena_Park_na_Gorze_Wyzwolenia_w_Chorzowie [dostęp: 12.12. 2018].

Kajdanek K., Banaszak E., Błaszczyk M., Pluta J., Specjalne weekendy Esk, raport podsumowujacy. Ewaluacja Europejskiej Stolicy Kultury, Uniwersytet Wrocławski, Urząd Miasta Wrocławia, Biuro Festiwalowe IMPART, Wrocław 2016.

Kłoskowska A., Otwarte i zamknięte postawy narodowe w sytuacji pogranicza, Kultura i Społeczeństwo, 1995, 39, 3.

Knas K., Ważne jest miejsce pamięci, Wspólny Chorzów, 2006, 12(135).

Knight J., Questioning Local Boundaries. A Critique of the "Anthropology of Locality", Ethnos, 1994, 59, 3-4.

Krawczak E., Antropologia kulturowa, klasyczne kierunki, szkoły i orientacje, Wydawnictwo Uniwersytetu Marii Curie-Skłodowskiej, Lublin 2006.

Langer S.K., Philosophy in a New Key, Harvard University Press, Massachusetts - London - Cambridge 1957. 
Langer S.K., Nowy sens filozofii, przekł. A.F. Bogucka, Państwowy Instytut Wydawniczy, Warszawa 1976.

Malinowski B., Kultura, społeczność, jednostka, przekł. S. Kapralski, J. Otrębski, Wydawnictwo Naukowe PWN, Warszawa 1999.

Melosik Z., Teoria i praktyka edukacji wielokulturowej, Oficyna Wydawnicza Impuls, Kraków 2007.

Melosik Z., Kultura popularna i tożsamość młodzieży. W niewoli władzy i wolności, Oficyna Wydawnicza Impuls, Kraków 2013.

Nikitorowicz J., Sobecki M. (red.), Edukacja międzykulturowa w wymiarze instytucjonalnym, Wydawnictwo Uniwersyteckie Trans Humana, Białystok 1999.

Nikitorowicz J., Pogranicze, tożsamość, edukacja międzykulturowa, Wydawnictwo Uniwersyteckie Trans Humana, Białystok 2001.

Nikitorowicz J., Halicki J., Muszyńska J. (red.), Międzygeneracyjna transmisja dziedzictwa kulturowego. Społeczno-kulturowe wymiary przekazu, Wydawnictwo Uniwersyteckie Trans Humana, Białystok 2003.

Nikitorowicz J., Halicki J., Muszyńska J. (red.), Kultury narodowe na pograniczach, Wydawnictwo Uniwersyteckie Trans Humana, Białystok 2006.

Ogrodzka-Mazur E., Między etnicznościa a integracją. Strategie kulturalizacyjne przyjmowane przez społeczności szkół z polskim językiem nauczania, Lubelski Rocznik Pedagogiczny, 2017, XXXVI, 3.

Otte J., Szopa R., Symbole Chorzowa, Agencja Mediów Lokalnych „mediaL”, Chorzów 2000.

Przecławska A., Symbole w życiu współczesnej młodzieży - wyniki badań przeprowadzonych w środowisku dorosłej młodzieży Warszawy, Kultura i Społeczeństwo, 1995, 3.

Podsiad A., Stownik terminów i pojęć filozoficznych, Instytut Wydawniczy PAX, Warszawa 2000.

Ruczyński R., Tradycyjna urbanistyka a wspótczesne realizacje przestrzeni publicznych, [w:] Problemy kształtowania przestrzeni publicznych, red. P. Lorens, J. Martyniuk-Pęczek, Wydawnictwo Urbanista, Gdańsk 2010.

Saada-Ophir G., Borderland Pop: Arab Jewish Musicians and the Politics of Performance, Cultural Anthropology, 2006, 21, 2.

Sadowski A., Czerniawska M., Tożsamość Polaków na pograniczach, Wydawnictwo Uniwersytetu w Białymstoku, Białystok 1999.

Skinner B.F., Poza wolnościa i godnościa, przekł. W. Szelenberger, Państwowy Instytut Wydawniczy, Warszawa 1978.

Sztompka P., Socjologia. Analiza społeczeństwa, Wydawnictwo Znak, Kraków 1988.

Tuner J.H., Sociologia. Koncepcje i ich zastosowanie, Zysk i S-ka Wydawnictwo, Poznań 1988.

Tuner J.H., Struktura teorii socjologicznej, Wydawnictwo Naukowe PWN, Warszawa 2004.

Vermeulen H., Govers C. (red.), The Anthropology of Ethnicity, Het Spinhuis, Amsterdam 2000.

Walancik M., Działania edukacyjne $i$ oświatowe w pedagogice międzykulturowej stużące zapobieganiu wykluczeniu kulturowemu społeczności lokalnej - na przykładzie Königshütte - Królewskiej Huty - Chorzowa, [w:] Pedagogika międzykulturowa wobec wykluczenia społecznego i edukacyjnego, red. T. Lewowicki, A. Szczurek-Boruta, J. Suchodolska, Wydawnictwo Adam Marszałek, Cieszyn - Warszawa - Toruń 2011.

Whitehead A.M., Symbolism. Its Meaning and Effect, Fordham University Press, New York (1927) 1985.

Zawadzki W., Longplay dla Ryśka, „Chorzowianin”, 2006, 45, (318). 